\title{
Problem Based Learning: A Student-Centered Approach
}

\author{
Sheeba Sardar $\mathrm{Ali}^{1}$ \\ ${ }^{1}$ Department of English, College of Science and Humanities, Majmaah, University, Al-Majmaah, Saudi Arabia \\ Correspondence: Sheeba Sardar Ali, Department of English, College of Science and Humanities, Majmaah, \\ University, Al-Majmaah, Saudi Arabia.
}

Received: February 24, 2019 Accepted: April 8, 2019 Online Published: April 11, 2019

doi: 10.5539/elt.v12n5p73

URL: https://doi.org/10.5539/elt.v12n5p73

\begin{abstract}
Problem-based learning is a teaching method in which students' learn through the complex and open ended problems. These problems are real world problems and are used to encourage students' learning through principles and concept. PBL is both a teaching method and approach to the curriculum. It can develop critical thinking skill, problem solving abilities, communication skills and lifelong learning. The purpose of this study is to give the general idea of PBL in the context of language learning, as PBL has expanded in the areas of law, education, economics, business, social studies, and engineering. It encourages students to develop skills that can be useful for their future and in practical life within a team environment. For the language classroom in Arab countries, where English is spoken as a foreign language PBL can be very useful. Trained teachers can design problems to meet the needs of the learners, that can be useful to improve English practically in social context.
\end{abstract}

Keywords: problem based learning, curriculum, collaborative learning, team work, approach, method

\section{Introduction}

Problem based learning is a student-centered educational method which aims to develop problem - solving skills through a self- directed learning as a life time habit and team work skills. Untidy, messy, ill structured situations are given to the students in which they take the role of owner of the situation. Students observe the problem and learn about the solution, compared to traditional lecture based learning, we have many advantages from PBL. Some of the advantages are as- makes learning useful to the real world, encouraging and motivating how to learn, engage students learning similar to real world. PBL not only focus on problem solving but also responsible for the development of other skills and attribute. As stated by Larson (2001), students in PBL classroom improve their social skills as they have more opportunities to practice using the language for authentic communication. PBL can be difficult to implement in a traditional classroom setting if students and teachers trouble understanding active or meaningful. PBL requires to students to engage in active learning strategies as a self -directed learning disposition. It represents a paradigm shift from teaching in a traditional way and learning philosophy.

\subsection{Meaning of PBL}

PBL is a process that is used to identify problems with a scenario to increase the knowledge and understanding. Some of the principles are listed below.

1) Independent and self- directed learning

2) Learning happens in a group and teacher is a facilitator.

3) All groups have to participate equally.

4) Students' learn about motivation, teamwork, problem-solving and engagement with the task.

5) Materials such as Data, photographs, articles, can be used to solve the problem.

Problems have always mobilized and stimulated thinking and learning, when problems are experienced as relevant and important they energize our activity and focus our attention, people are motivated to redirect their energies towards solving them. Although Problem-based learning has appeared since the dawn of time, in higher education.Now in the $21^{\text {st }}$ century teachers and in other professionals across the globe using PBL in various disciplines. Many teachers in higher education are now highly experienced in the design and use of problems and are comfortable with PBL methodologies that have been part of the higher education. PBL can be united into any 
learning situation. Critical thinking skills, problem-solving abilities, and communication skills are the outcome of PBL. It can enhance the ability of collaborative skills, finding and evaluation for life-long learning.

\section{Traditional Versus Problem-Based Learning}

In traditional approaches to learning based on traditional way, data is provided first in traditional way of learning, but in PBL problems are presented to the students' to solve the problem. Figure 1 represents the process of learning and showing how each step is inter-connected to each other.

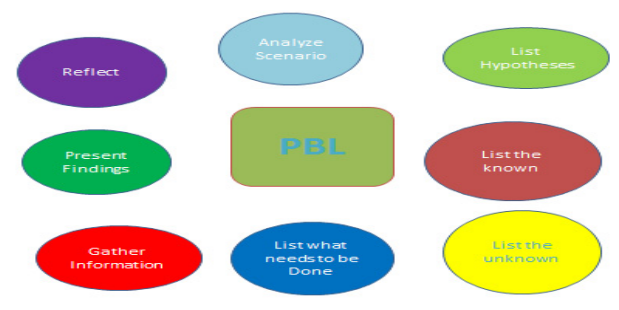

Figure 1. The process of learning (PBL)

The challenges are heightened when teachers are unable to facilitate group discussions, construct valid problems, and guide students through the problem solving process. Similarly, students fail when they are unable to work well in groups, actively generate resolutions or ideas related to the problem. Students may also fail in terms of critical analysis which is vital in PBL.

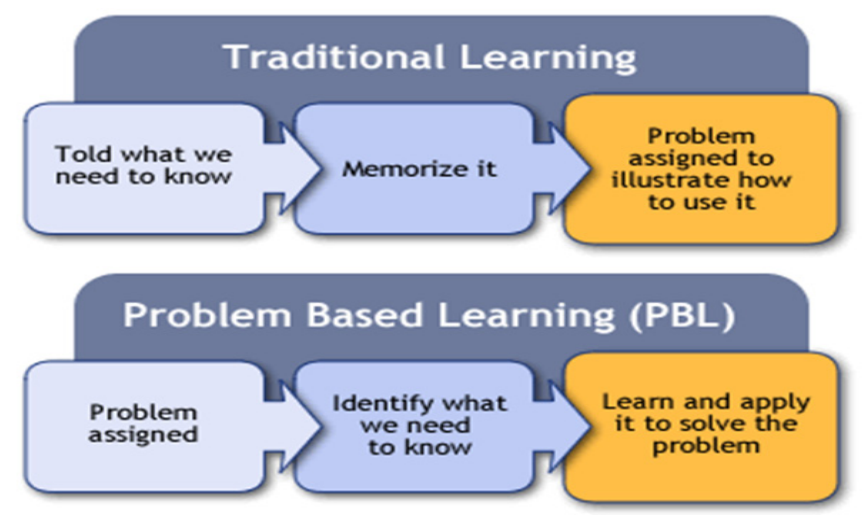

Figure 2. Difference between traditional learning and PBL

\subsection{Sample Activities for Traditional Based Learning VS Problem-Based Learning in English Language Classroom}

\section{Traditional based learning \\ You are teaching a unit in your writing class on poetry. To evaluate your students' understanding, you give a quiz on the various forms of poetry. \\ You are teaching a unit in Syntax, sentence structure in English Language. To evaluate your students' understanding give them short assignment to write examples for each.}

You are teaching a unit in Phonetics on sounds and letters. To evaluate your students' understanding, give a quiz to ask examples for each sound and letters.

\section{Problem based learning}

Present students with a similar theme and have them write a poem in a specific format or style; what form is most effective and why.

Ask students to present similar sentence structure in some other languages with examples.

Present students similar theme and ask them to write sounds and letters of their native language and discuss problems faced by them to learn English sounds and letters. 


\subsection{Instructor's Role in Problem based Learning}

With the help of the diagram given below we can easily understand the role of instructor and learners. The instructor is responsible to design and identifies problems that should be complex and vague to encourage students to inquire about it. They can do the research with reasonable solutions and conclusion. Teacher should design the problem to suit the course, new and unfamiliar, and relevant to use in work environments. Teacher is mentor, facilitator, and a coach with students can work in teams collaboratively. Teacher can make different groups with different skills to achieve more variations and outcomes.

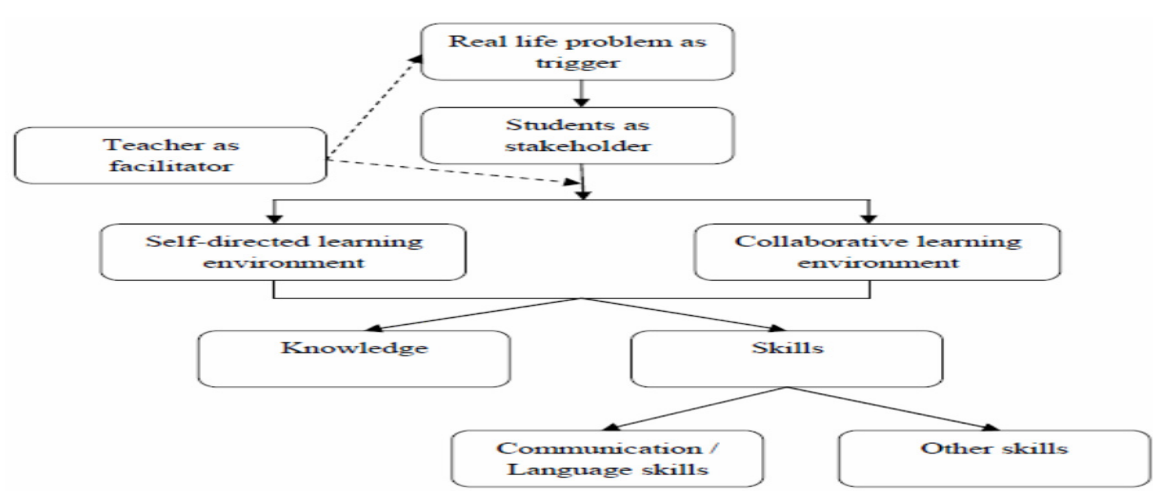

Figure 3. The role of the teacher

\subsection{Students' Role in PBL}

During PBL, students take up different roles to solve the presented problem. They change the role as note taker or team member. Students' explore the problem and schedule for their own activities in order to manage the problem. Through this exploration students' can examine their knowledge and skills also how to manage the time.

\subsection{Dimensions}

These points can be very helpful for the teacher to design and assign the problem to the students.

\subsubsection{Assigning the Problem}

Identify and discuss the important parts of the problem.

\subsubsection{Tutorials in Small Teams}

Current knowledge about the problem should relate to each team member. Teacher can identify the strength and capabilities of team members to explore the solution of the problem.

\subsubsection{PBL compatible Assessments}

This point can discuss the background knowledge and materials they need to solve this.

\subsubsection{Curriculum Development}

Here students can discuss the reasons, assumptions about the problem.

\subsubsection{Developing Knowledge and Capabilities}

Assigned problems should be related to the course and regarding their previous knowledge.

\subsubsection{List What Your Team Needs to Know to Solve the Problem}

List some of the reason and what we are going to do to solve this. Provide and discuss possible sources that are helpful such as internet, data and primary sources. Divide class in groups and assign them task what they have to do. After that, give them deadline to submit their problem.

\subsubsection{Each Group Member Has to Present the Report With the Solution and Supporting Material}

\subsubsection{Presenting and Defending Your Conclusions}

The main objective of PBL is not to present team's report but also the point where they start and drawn. For this we can consider the following points- 
a. Problem should be original with solution.

b. Explain the process of solving problem briefly.

c. Audience should be convinced with the solutions and steps followed.

d. Students should be ready for clearing their doubts.

\subsubsection{Focused Individual and Team Performance}

This can help students' to make learning environment for real life situations and they more observant to meaningful questions to solve the problem.

PBL is inquiry- based instructional model in which students are engaged with real world problems. While learning students' themselves identify gaps in their knowledge and can design research apply for future. According to these new methods learners can take the responsibility of their own learning. Through team work students can foster problem-solving, metacognitive skills and motivation.

\section{Theoretical underpinnings of PBL}

Some of the following key points are here for PBL learners

1). Students should have some background knowledge, assumptions and experiences.

2). Learning happens in collaborative setting in social context.

3). Unfamiliar information can be dealt with strategies applied, handling problems with well -designed solutions.

4). Learner centered problems should be designed.

5). Self-directed learning can take place.

6). Problem solving can incites for learning.

7). Throughout the learning process, critical reflection happens

The main important point of this approach is that students are responsible for their own learning, learn how to use prior knowledge and the way of knowledge acquisition. The PBL approach gives more focus on self and peer assessment, communication and interpersonal skills. It is observed that PBL motivates deep learning, students learn for understanding and seeking meaning, whereas the teacher-centered approach to help brings plane learning with less understanding. Some theorists believe that PBL can improve new way of thinking and learning. This will enhance their personal growth, more active, increase confidence and responsibility. In small groups students can share their problem, able to express their ideas in a better way, improving their conceptual knowledge and managing problem situations.

\section{For Applying PBL in our Classes Teacher Can Design and Implement Some of the Basic Steps}

1) First of all, identify learning outcomes that can be fit with PBL. After that, assessments, learning reflections, creating rubrics that are important for PBL assessments can be developed by the teacher.

2) Make some outline with a real problem that will emerge through students brainstorming. The problem should be real and related to the course. It is very important to design suitable problems that motivates them to think, discuss, research and learning.

3) Students can begin their research with an "easy" problem and teacher can introduce the expectations. Teacher can organize some sessions regarding the problem assigned to them (background knowledge) research topics, finding data, etc. After that students can decide their roles and responsibilities to understand the problem completely.

4) Students' can present and synthesize resources to develop their research, findings, solutions, and learning.

5) Teacher can create rubrics to determine whether students' have participated meaningfully. This type of research can be very useful for their future study also.

\section{Merits and Demerits of PBL}

PBL nurtures active and life-long learning skills. It enhances self-directed learning to face students with the problems and stimulates them towards deep learning, it means "elaboration of knowledge at the time of learning." Collaborative learning will allow them to-

Address real life situations, appealing to students who struggle to grasp abstract concepts.

Participation in groups, helping those students who don’t excel during solo work grasp new material. 
Discuss possible ideas and challenges in a formative manner. Students are engaged completely in searching, collecting data to find the solution for the problem assigned to them.

Because of the continuous engagement with the students' teacher- student relationship improves. In PBL classroom teacher is not in a traditional form, here he is facilitator, mentor and guide. Students feel free to discuss with teacher.

Classroom setting in PBL is completely different, they present their ideas in groups defend and revise if it's needed. It helps them to create successful interaction and communication.

Most of the time students' are busy with PBL, so that they can face the problem to achieve good scores.

PBL demands complete engagement and involvement of the students, but for all the students' it can be difficult all the time. Sometimes they can feel disengaged. Participation can be delayed due to-

Some students' are immature to understand the problem.

Students' are not able to understand the idea of open-ended problem.

Students' may require abstract knowledge to create and finding the solution of the problem.

For supervising PBL activity teachers should be trained so that they can give focus on-

Chalked out about the problem.

Designing Questions.

Providing helping material

Question answer series

PBL exercise demands constant monitoring and note taking.

Teacher can take factors into account such as-

Tasks completion

Qualitative Research

Overall performance.

Interaction among team members

Creating rubrics

PBL is considered as a constructive approach because essential components are feedback and reflection on the learning process. Students work as an active agents in the construction of social knowledge.

\section{Conclusion}

Through PBL students' learn to work in groups, become partners in teaching/ learning process where they can work successfully, can deal new situations and develop life- long learning skills. The silent way is one of the method developed in 1970s to highlight the cognitive domain in learning. The silent way focuses on discovery, creativity and problem solving including teaching materials. The main objective of this approach is to improve the overall competency and skills of the students. Key advantage of this method is to familiarize students with real world problems and improves their confidence. It also enhances networking skill, value of team work and appreciation of interdisciplinary approach. But this approach needs consideration of the mentor, communication between the team to achieve the necessary milestones. In 2008, Al Jouf University of Sakakah, Saudi Arabia, and Al-Faisal University Riyadh, Sulaiman Al-Rajhi College(Qassim started using PBL for all their medical programs. Therefore, for language classes it can be very useful so the teachers should be trained to design and assign problems for the suitable situations and courses. As a language teacher, one's feel for the EFL learner's PBL can be helpful to overall improvement.

\section{References}

Allen, D. E., Duch, B. J., \& Groh, S. E. (1996). The power of problem-based learning in teaching introductory science courses. In L. Wilkerson, \& W. H. Gijselaers (Eds.), Bringing Problem-Based Learning to Higher Education: Theory and Practice (pp. 43-52). San Francisco: Jossey-Bass. https://doi.org/10.1002/tl. 37219966808

Anton, P. (1990). Student perceptions of problem-solving activities in an ESL classroom. TESOL Quarterly, 233(1), 14-17.

Barrows, H. S., \& Tamblyn, R. M. (1980). Problem-based learning: An approach to medical education. New 
York: Springer Pub. Co.

Boud, D. J., \& Feletti, G. I. (1994). Introduction. In D. J. Boud, \& G. I. Feletti (Eds.), The challenge of problem-based learning. London: Kogan Page.

Boud, D., \& G. Feletti. (1997). The Challenge of Problem Based Learning. London: Kogan Page.

Candy, P. C. (1991). Self-direction for lifelong learning: A comprehensive guide to theory and practice. San Francisco: Jossey-Bass.

Chen, C. M., \& Chia-Chi Chen, C. C. (2010). Problem-based learning supported by digital archives; Case study of Taiwan Libraries' History Digital Library. The Electronic Library, 28(1), 5. https://doi.org/10.1108/ 02640471011005414

Copland, M. (2001). Speaking of Teaching. Stanford University Newsletter on Teaching, 11(1).

Duch, B. J. (1995). The power of problem-based learning. A Newsletter of the Center for Teaching Effectiveness. Retrieved October 20, 2004, from http://www.udel.edu/pbl/cte/spr96-bisc2.html

Eckerth, J., \& Siekmann, S. (2008). Task-based language learning and teaching: Theoretical, methodological, and pedagogical perspectives. Frankfurt am Main: Peter Lang.

Huang, J. (2010). Grammar Instruction for Adult English Language Learners: A Task-Based Learning Framework. Journal of Adult Education, 39(1), 29-39.

Kam, P. W., \& Chi, B. L. (2007). Problem-based learning in social work: A study of student learning outcomes. Research on Social Practice, 17(1).

Larsen-Freeman, D., \& Anderson, M. (2011). Techniques and Principles in Language Teaching (3rd ed.). Oxford: Oxford University Press.

Mardziah, H. A. (2005). Problem-based learning in language instruction: A constructivist method. ERIC Clearinghouse on Reading, English, and Communication Digest \#132.

Mavis, B. E., \& Wagner, D. P. (2006). Comparing problem-based learning and lectures. Academic Exchange Quarterly, 10(4).

Richards, J., \& Rodgers, T. (2001). Approaches and methods in language Teaching (2nd ed.). Cambridge: Cambridge University Press. https://doi.org/10.1017/CBO9780511667305

Tan, O. S. (2003). Problem-based learning innovation. Singapore: Thomson.

White, H. B. (1996). Dan tries problem-based learning: A case study. In L. Richlin (Ed.), To Improve the Academy, 15, 75-91. https://doi.org/10.1002/j.2334-4822.1996.tb00303.x

\section{Copyrights}

Copyright for this article is retained by the author(s), with first publication rights granted to the journal.

This is an open-access article distributed under the terms and conditions of the Creative Commons Attribution license (http://creativecommons.org/licenses/by/4.0/). 